http://www.banglajol.info/index.php/JBS/index

\title{
INFLUENCE OF MOISTURE CONDITIONS ON THE STRUCTURE OF LITTER INVERTEBRATE COMMUNITIES IN SHELTERBELT AND PLANTATION FORESTS IN SOUTHERN UKRAINE
}

\author{
Viktor V Brygadyrenko* \\ Oles' Honchar Dnipropetrovsk National University, Department of Zoology and Ecology, \\ pr. Gagarina, 72, 49010 Dnipropetrovsk, Ukraine
}

\begin{abstract}
Context: The distribution of different size groups of litter invertebrates in varying gradations of moisture conditions is therefore of interest for a better understanding of the coordination of the components of the ecological community.

Objectives: The aim of this work is to evaluate the effect of long-term average moisture conditions on the basic characteristics of the litter macrofauna of plantations in southern Ukraine.

Materials and Methods: Invertebrates were collected with pitfall traps annually throughout the vegetational seasons of 2001-2013 in 176 plantation sites.

Results: The average number and the quantity of invertebrate species in the litter decreases with the increase of the moisture content. The indices of biological diversity are maximal in xeromesophilous and mesophilous moisture conditions. Phytophages are distributed evenly in the litter of forest plantations. The number of saprophages is maximal in xeromesophilous (36\%) and minimal - in hygromesophilous (3\%) conditions. Zoophages increase in relative abundance from $14 \%$ in mesoxerophilous to $63 \%$ in hygromesophilous conditions. The abundance of polyphages does not change significantly in varying gradations of moisture (26-46\%). The size structure of communities is dominated by the group ranging from 4 to $7 \mathrm{~mm}$ in body length (31-52\%). The relative abundance of the size group exceeding $20 \mathrm{~mm}$ in body length reaches its maximum (16\%) in mesoxerophilous conditions, and decreases (4-10\%) in other gradations of moisture. The share of the size group of $<4 \mathrm{~mm}$ is maximal (28\%) in mesophilous conditions. Carabidae, Formicidae and Lycosidae form part of the dominant families in all four of the moisture gradations of artificial forests studied, while other families represent more than $3 \%$ only in plantations belonging to three gradations of moisture.

Conclusion: Litter moisture is a limiting factor for invertebrate existence in the extreme conditions of forest ecosystems, especially in the south of the steppe zone of Ukraine.
\end{abstract}

Key words: forest ecosystems, trophic structure, structure of domination, biodiversity.

\section{Introduction}

Moisture is the most important environmental factor in arid habitats. It affects the development of herbaceous and woody vegetation as well as the animal communities connected with them. Invertebrates make active and passive (through falling from leaves), vertical and horizontal migrations within forest ecosystems in response to changes of humidity, selecting optimal hydrothermal conditions for their trophic activity, and in adverse conditions, falling into diapauses. The southern part of Ukraine falls within the steppe zone, where lack of precipitation is characteristic during the summer (the dominant influence on atmospheric circulation is produced by anticyclones). A significant proportion of precipitation during the vegetational growth season comes in the form of violent, intense downpours which lead to short-term water logging of the soil and litter (in this text litter is understood as the organic, upper layer of the soil). However, most of the summer is dominated by drought. The seasonal variability of moisture conditions determines the environmental

\footnotetext{
* Corresponding author E-mail: brigad@ua.fm
} 
characteristics of artificial forest ecosystems, which represent most of the forest vegetation in southern Ukraine.

The litter fauna (elements of which are able to partially replace each other in the functioning of a forest ecosystem) reacts to changes of conditions in different ways. So far, no wide-ranging studies of the litter fauna of the forest-steppe zone based on dozens of forest sites have not been carried out. The total number of forest sites that have been analysed in the few works devoted to the effect of individual ecological factors on the arid forests of Ukraine does not exceed 40 (Brygadyrenko 2005, Moroz et al. 2011). However, local studies on their own are insufficient as a basis for drawing general conclusions on the impact of a given environmental factor on litter fauna (Faly \& Brygadyrenko 2014). It is possible in this way only to estimate the response strategies of individual populations of invertebrates. The influence of hydrological conditions on certain types of macrofauna has been studied in detail, but there is little data on how this factor influences the macrofauna of forest ecosystems (Cameron et al. 1980, Gerisch et al. 2006, Persson et al. 2013, Rainio \& Niemela 2003). The reaction of definite species of litter macrofauna to certain factors (e.g. flooding of groundwater from mines, influence of road traffic, establishment of shelterbelt plantations, salination of meadows) affecting forest ecosystems of the steppe zone of Ukraine has been studied in our previous works using multivariate statistical methods (Brygadyrenko 2004, 2014).

In the critical conditions of insufficient moisture, the degree of disorder and and variability in the proportions of species and their ecological groups in the community structure increases, and so does the entropy of the system (Bogaert et al. 2005). The most noticeable changes happen (Dennis \& Fry 1992, Floate et al. 2007, Irmler 2003, Jabin et al. 2004, Major et al. 2006, Oxbrough et al. 2012) in ecosystems under intense anthropogenic pressure (atmospheric pollution from industrial emissions, exposure to pesticides and fertilizers from adjacent agricultural lands, the fragmentation of forest habitat, invasion of alien species of plants and animals, etc.). The majority of plantation ecosystems in Ukraine consist precisely of such ecosystems. The complexity of the ecological structure of the animal populations of shelterbelts (linear windbreak plantations dividing fields) in agricultural landscapes is primarily due to a local ecotone effect created by the contact of the invertebrate communities of the steppe or field zone with forest communities, which are uncharacteristic for this climatic zone (Burel \& Baudry 1990, Burel 1996, de la Peña et al. 2003; Didham 1997, Hanski 1999, Maudsley et al. 2002, McNabb et al. 2001, Petit \& Burel 1998, Roslin \& Koivunen 2001, Wamser et al. 2011, Zeng et al. 2009).

The loss of species diversity of litter fauna will over time have an impact on the results of agricultural and silvicultural activity both at local and at the level of regional economies (Duelli et al. 1999, Hendrickx et al. 2007, Hietala-Koivu et al. 2004, Scăunaşu et al. 2012), as a large number of predatory invertebrate species inhabit the litter and play an important role as antagonists of pest species and in the process of vegetational decomposition. Being highly dependent on their high ratio of surface, invertebrate animals of a smaller size are more susceptible to loss of moisture. For this reason, the reactions of litter mesofauna (invertebrates of up to $2 \mathrm{~mm}$ in length) to the changes of moisture conditions have been studied more fully in the case of small invertebrates. The relatively larger objects of the macrofauna (invertebrates of over $2 \mathrm{~mm}$ in length) have in this respect received far less attention (Thiele 1977, Gaston \& Blackburn 1996, Gerisch et al. 2006). The distribution of different size groups of litter invertebrates in varying gradations of moisture conditions is therefore of interest for a better understanding of the coordination of the components of the ecological community.

The aim of this work is to evaluate the effect of long-term average moisture conditions on the basic characteristics (total number of invertebrates, number of species, Shannon and Pielou index, the trophic, size, and taxonomic structure) of the litter macrofauna of plantations in southern Ukraine. 


\section{Material and Methods}

Invertebrates were collected with pitfall traps $(500 \mathrm{ml}, 85 \mathrm{~mm}$ in diameter of opening, with $20 \%$ solution of $\mathrm{NaCl}$ ) annually throughout the vegetational growth seasons (beginning of April to end of September) of 2001-2013. Soil traps were checked every 5-7 days for the period of 20-185 days (from 3 to 24 , on average 10 traps for each sampling plot). In order to compare the community structures we analyzed in every year a single 20-day time period (in mid-June) for each sampling plot. We selected this period because, falling between the end of the spring rainy season mid May-beginning of June when up to $100 \mathrm{~mm}$ falls) and the onset of the summer drought season (lasting from the end of June to the end of August), it offered the greatest variety of invertebrate species. Collection was not made during rainy periods (when the traps were flooded with water and collection would have been impossible. Similarly, collection was not carried out during periods of drought because in these conditions invertebrates in the steppe zone reduce their activity by 10 to 100 times and therefore the numbers caught in the pitfall traps are negligible.

A total of 176 plantation sites, each measuring $10 \times 10$ meters and continuously and evenly vegetated, were studied with the following dominant plants: Robinia pseudoacacia L. (62 sites), Fraxinus excelsior L. (48), Gleditsia triacanthos L. (18), Quercus robur L. (15), Acer tataricum L. (5), Malus domestica Borkh. (5), Betula pubescens Ehrh. (4 sites).

The plantations varied in age from 20 to 150 years, the majority of plantations in the steppe zone being established in the 1950s and 1960s. The majority occupy areas of common black soil or light clay, on a slight incline. The elevation of the sites ranges from 60 to 150 meters above sea level. The sites were a minimum of $2 \mathrm{~km}$ apart and in total covered an area $400 \mathrm{~km}$ west to east and $250 \mathrm{~km}$ south to north.

We used pitfall traps in preference to litter sifting methods because the former yield a more varied species composition, including a greater number of rare and mobile species. In our previous work we have tried sifting methods but have found that they bring rather disappointing results. This is partly due to the vertical migrations performed by many species of litter invertebrates of the steppe zone in response to changes in temperature, light and moisture regimes within plantations. Many litter invertebrate species descend to the soil layer during the day and are therefore not available to be caught through litter sifting, but ascend to the litter layer at night when they are more active and are therefore liable to be caught in pitfall traps. A key advantage of pitfall traps in this respect is that they operate over a prolonged period, accumulating every specimen that falls into them between the moment of setting up and the moment of checking, whereas the sifting method only reveals what is present at one particular moment.

Each trap site was characterized by one of the following moisture regimes: mesoxerophilous, xeromesophilous, mesophilous and hygromesophilous. Of course, mesohygrophilous, hygrophilous and ultrahygrophilous types of ecosystems are not used by man to create artificial forest ecosystems. Moisture regimes were classified according to the standard scale (Belgard 1971), using the composition of the herbaceous plant community. Collection was carried out on the territory of southern and central Ukraine (Dnipropetrovsk, Zaporizhzhya, Mykolaiv, Donetsk and Kharkiv regions).

We identified all invertebrate macrofauna collected in the traps at species level for Carabidae, Hemiptera, Formicidae; all other invertebrate macrofauna were identified at genus level. Mesofauna were not analysed. The trophic specialisation of each invertebrate taxon was identified using literary sources and our own laboratory experiments. The size structure of each taxon was characterised by the average measurement for 10 or more specimens. To assess the diversity of litter invertebrate communities, the best-known indices, the Shannon and Pielou indices were used (Shannon \& Weaver 1949, Pielou 1977). Statistical processing of the results was carried out in Statistica 8.0. The differences between the values of the characteristics of different types of shelterbelt and forest plantations were considered statistically significant at $P<0.05$. We performed single factor dispersal analysis on the data, by the Fisher F-criteria. 


\section{Results}

\section{The main characteristics of communities}

With the increase of soil moisture, the average number of invertebrates in the litter decreases (Fig. 1a) from 66.9 and 81.0 in mesoxerophilous and xeromesophilous moisture conditions to 40.0 and 25.5 samples per 100 trap-days in mesophilous and hygromesophilous moisture conditions. This is primarily due to a sharp decline in the number of Formicidae. The number of species of litter invertebrates changes in the same way (Fig. 1b): it reaches its maximum in xeromesophilous conditions (26.1 species) and decreases towards the drier (up to 16.5 in mesoxerophilous) and more humid (14.1 in mesophilous and 17.7 in hygromesophilous) moisture conditions. The mean values according to the Shannon-Weaver (Fig. 1c) biological diversity index attain their maximum in xeromesophilous and mesophilous conditions (by 3.05 bits), then they decrease in drier (mesoxerophilous - 2.45) and more humid (hygromesophilous 2.75) moisture conditions.

(a)

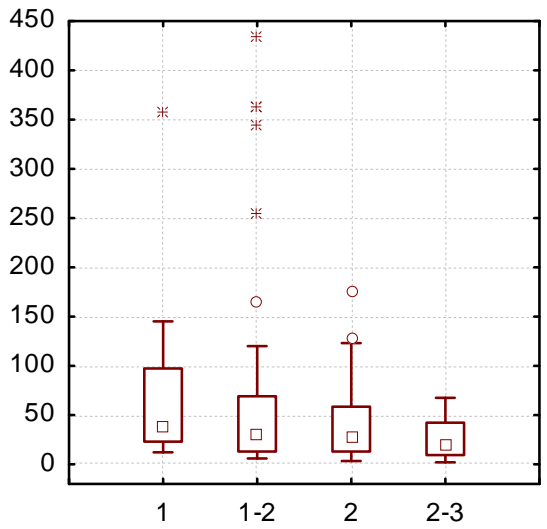

(c) 5.0

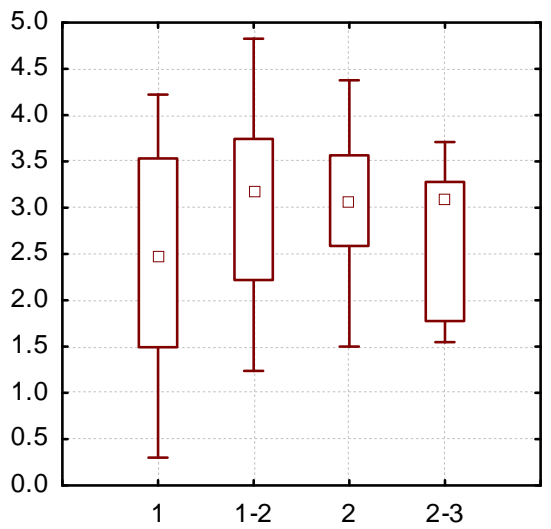

(b)

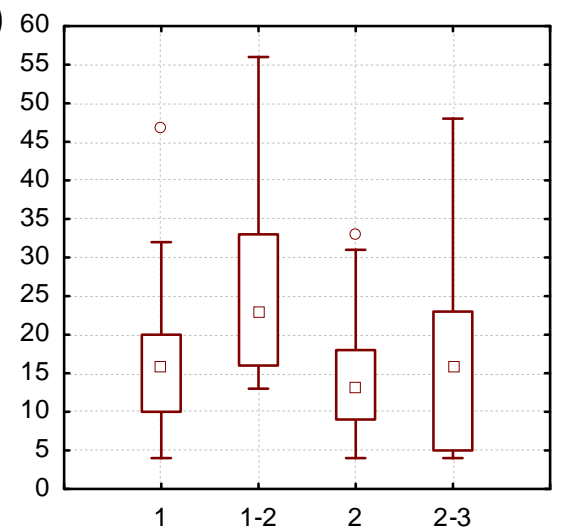

(d)

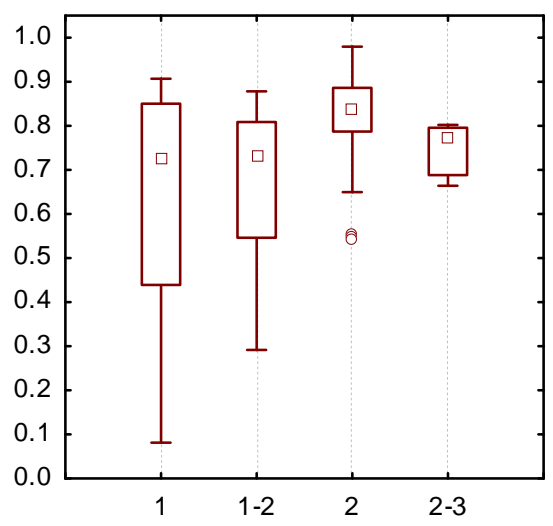

Fig. 1. The main characteristics of litter invertebrate communities of shelterbelt and forest plantation sites in the steppe zone of Ukraine depending on moisture conditions: (a) - total number (samples/100 trap-days), (b) - number of species, (c) - Shannon index (bits), (d) - Pielou index (bits); abscissa - moisture conditions (1 - mesoxerophilous, 1-2 - xeromesophilous, 2 - mesophilous, 2-3 - hygromesophilous), ordinate - values of characteristics 
The Pielou index (Fig. 1d), reflecting the structure of domination in the community, levels the impact on diversity of the number of species. That is why its values are significantly reduced in the forest plantations dominated by Formicidae (mesoxerophilous -0.639 and xeromesophilous -0.661 ), and then they increase moderately in the following conditions: mesophilous -0.832 and hygromesophilous -0.752 bits.

\section{Trophic structure}

The number of phytophages (Fig. 2a) in the litter of the forest plantations of various moisture conditions does not vary significantly, making up $3.4-9.5 \%$ of the total number of invertebrates. The maximum number of species is observed in xeromesophilous conditions, the minimum in hygromesophilous conditions. This is due to the formation of a fairly thick layer of litter as moisture increases. The layer prevents the germination of seeds of herbaceous plants and shrubs (basic diet of litter phytophages under the canopy).

(a)

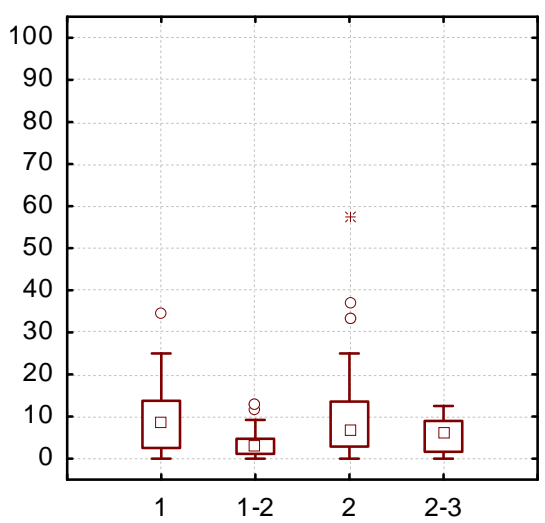

(c)

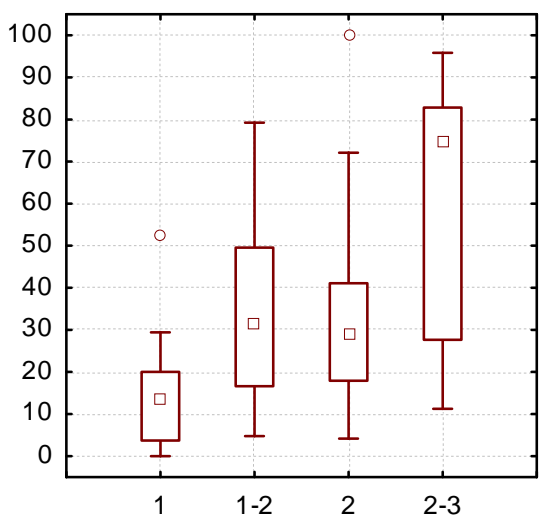

(b)

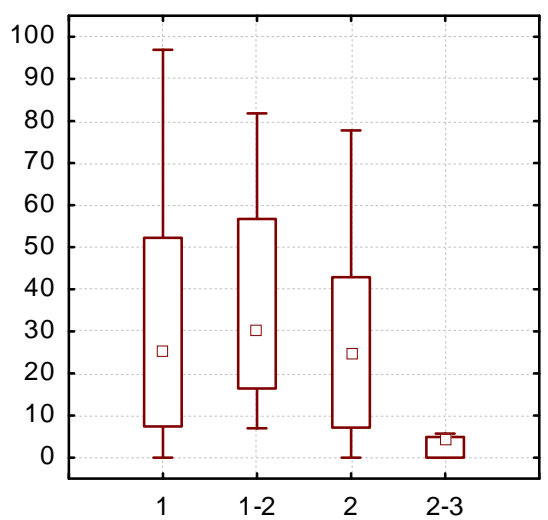

(d)

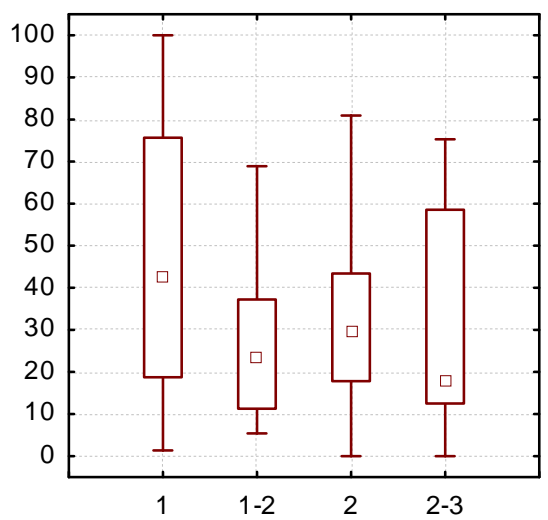

Fig. 2. Trophic structure of litter invertebrate communities of shelterbelt and forest plantation sites in the steppe zone of Ukraine depending on moisture conditions: (a) phytophages, (b) saprophages, (c) zoophages, (d) polyphages; abscissa moisture conditions (1-mesoxerophilous, 1-2 - xeromesophilous, 2 - mesophilous, 2-3 - hygromesophilous), ordinate - share of the trophic group in number $(\%)$

The decrease in the average number of saprophages becomes much more pronounced as the moisture gradient increases (Fig. 2b). This number reaches its maximum in xeromesophilous (36.4\%) and its minimum in hygromesophilous $(2.9 \%)$ moisture conditions. The average number of saprophagous species increases from mesoxerophilous (3.2 species) to xeromesophilous conditions (6.4), and then decreases again in 
mesophilous conditions (3.2), reaching its minimum in mesohygrophilous (1.7 species) moisture conditions in shelterbelts and forest plantations in Ukraine.

Zoophages significantly increase their relative number (Fig. 2c) with increasing humidity in the forest ecosystem (from $14.2 \%$ in mesoxerophilous to $63.2 \%$ in hygromesophilous conditions). The absolute number of zoophages reaches its minimum in mesoxerophilous conditions (9.52 samples/trap-days), reaches its maximum in xeromesophilous conditions (27.7) and decreases in mesophilous (12.6) and hygromesophilous (16.1) moisture conditions. The average number of zoophage and saprophage species on sampling plots share a similar dynamic: their number is minimal in mesoxerophilous conditions (5.1 species), maximal in xeromesophilous conditions (10.9) and is at an intermediate level in mesophilous (5.6) and mesohygrophilous (8.4) moisture conditions. Saprophages and zoophages both from forest ecosystems and from adjacent virgin steppe areas or agricultural lands are widely spread.

Polyphages do not change their number significantly in various moisture conditions (Fig. 2d), making up on average $25.9-46.2 \%$ of the community in numbers. The average number of polyphages species varies from 3.2 to 5.5 , and does not change significantly in various moisture conditions.

There is a noticeably significant variation in the proportion of sapro-, zoo-, and polyphages in the litter community structure. This is due to the restructuring of the community structure at the taxonomic level (not so much within the range of orders or families as at the species level) in the same moisture conditions. In the absence of extreme fluctuations in humidity and temperature (xeromesophilous and mesophilous conditions in the steppe zone of Ukraine) the community of litter invertebrates still changes its structure significantly when certain types of dominants disappear. Under such conditions, it is possible to find structurally very different invertebrate communities under the canopy of one and the same species of tree.

\section{Size structure}

Attention is drawn to four features of the size structure of shelterbelt and plantation forest communities (Fig. 3).

1. Intensity of the peak of dominance of the size group of $4-7 \mathrm{~mm}$ body length. Individuals of this size group make up 31.0-52.0\% (minimum - in mesophilous, maximum - in hygromesophilous moisture conditions) of the total number of litter invertebrates. In natural types of steppe zone forests, similar values for this peak (23.4-65.7\%) are noted. Extreme values of this characteristic manifest themselves in the communities highly disturbed by man or in the areas with a very high number of species of Formica or Myrmica, genera that destroy most other invertebrate species.

2. Numerical share of size group exceeding $20 \mathrm{~mm}$ body length. The maximum percentage of large forms $(16.5 \%)$ is typical of mesoxerophilous moisture conditions, decreasing significantly to $4.2-9.9 \%$ in the other moisture regimes. In the natural forests of the steppe zone individuals of this size group also do not exceed $10 \%$ in number in most of the surveyed sites. The increase in the proportion of large size groups reflects the total length of the most important trophic chains in an ecosystem, most of which for litter invertebrates of the forests of the temperate zone culminate in zoophages exceeding $20 \mathrm{~mm}$ in body length (in their turn eaten by predatory vertebrates).

3. Share in the invertebrate community of the smallest size group with the body length of less than $4 \mathrm{~mm}$. In natural forests of mesophilous moisture conditions the share of this size group exceeds $20 \%$ of the total number. A similar peak can also be observed in plantations under mesophilous conditions (28.3\%). For the remaining shelterbelt and plantation forest moisture regimes, the share of individuals with body length up to 4 $\mathrm{mm}$ comes to $12.5-20.9 \%$. The number of this size group is on the one hand an indication of the reserve of the trophic resources in the ecosystem necessary to ensure the existence of most species of zoophages and polyphages, and on the other hand indicates the consistency of hydrothermal conditions, fluctuations in which adversely affect species with the maximum ratio of body surface area to weight. 
4. Additional peaks (except for the size group of 4-7 mm) on the histogram of the size structure of the invertebrate community. Such peaks are present for the groups of $12-15 \mathrm{~mm}$ body length in mesoxerophilous and mesophilous conditions, and for the group of 16-19 mm body length - in hygromesophilous moisture conditions. In natural steppe forests, additional peaks in the size structure of the community rarely appear (we have recorded this phenomenon only for wetlands in hygrophilous moisture conditions). Additional peaks of the size structure indicate disturbance of a trophic net in the ecosystem; they show that species of different size groups can be found in these conditions at the top of certain, more substantial trophic chains of the community. The analysis of the qualitative composition of the size structure (the size structure of the community analysed by the number of species) reveals the same pattern. Thus, significant deviations compared to natural forests of the steppe zone have been observed in the size structure of invertebrate communities of the litter of plantation ecosystems - additional peaks appear for the groups of 12-15 and 16-19 body length in the histograms of the community size structure and the number of specimens in the size group with the body length of less than $4 \mathrm{~mm}$ decreases.

(a)

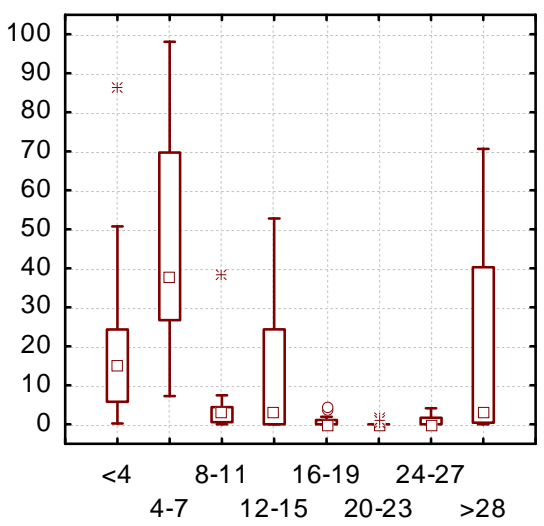

(c)

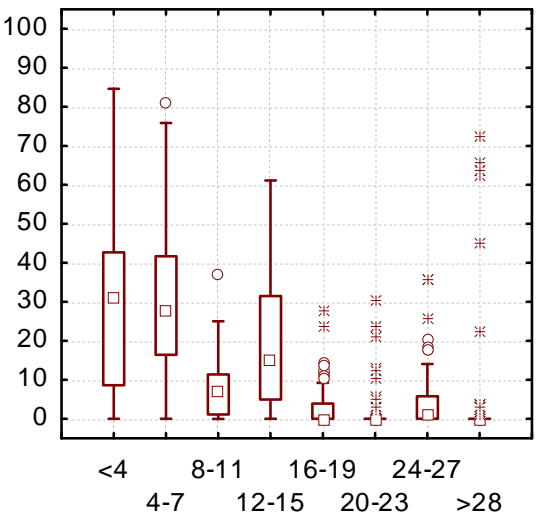

(b)

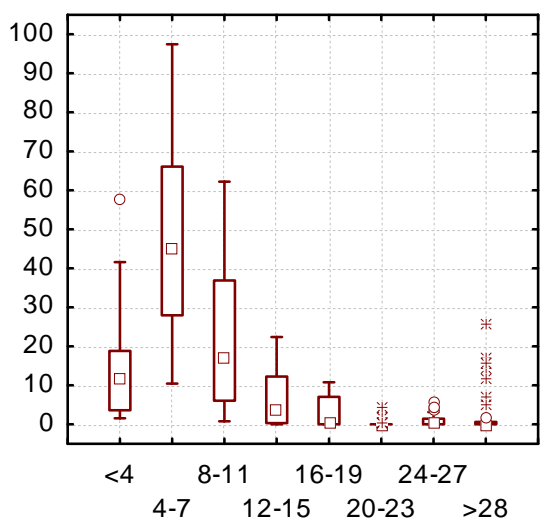

(d)

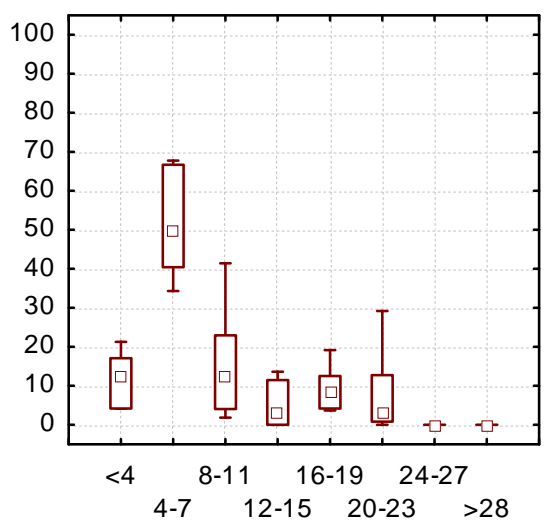

Fig. 3. Size structure of litter invertebrate communities of shelterbelt and plantation forest sites in the steppe zone of Ukraine depending on moisture conditions: (a) mesoxerophilous, (b) xeromesophilous, (c) mesophilous, (d) hygromesophilous moisture conditions; abscissa - the length of the body of individuals $(\mathrm{mm})$, ordinate - proportion of individuals of this size group in number (\%) 


\section{Taxonomic structure}

The groups exceeding 3\% of the total number of the community were considered as dominant in the taxonomic structure. Carabidae, Formicidae and Lycosidae form a share of the dominants in all four examined moisture regimes in plantation sites in the steppe zone of Ukraine (Fig. 4).

(a)

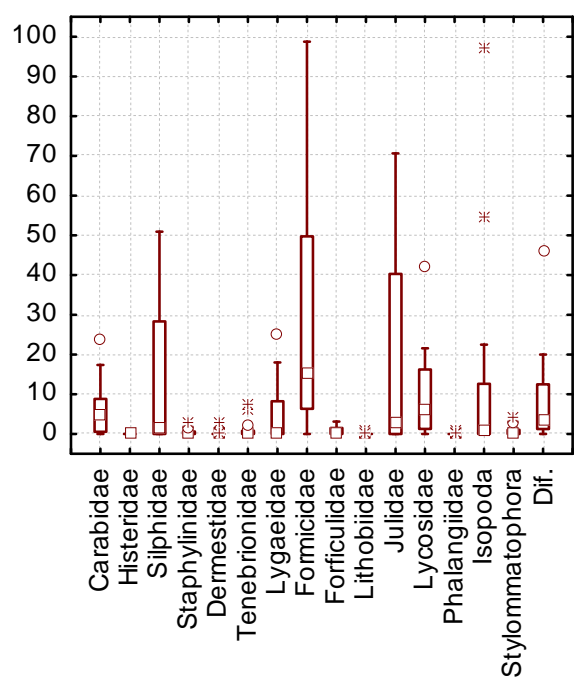

(c)

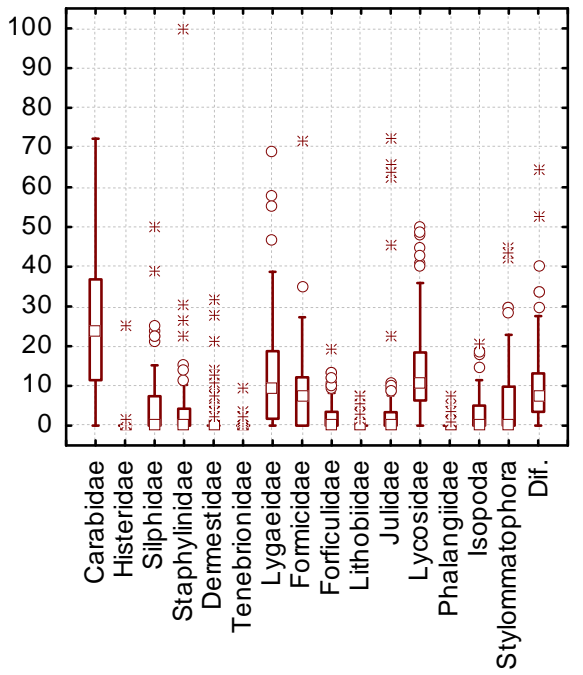

(b)

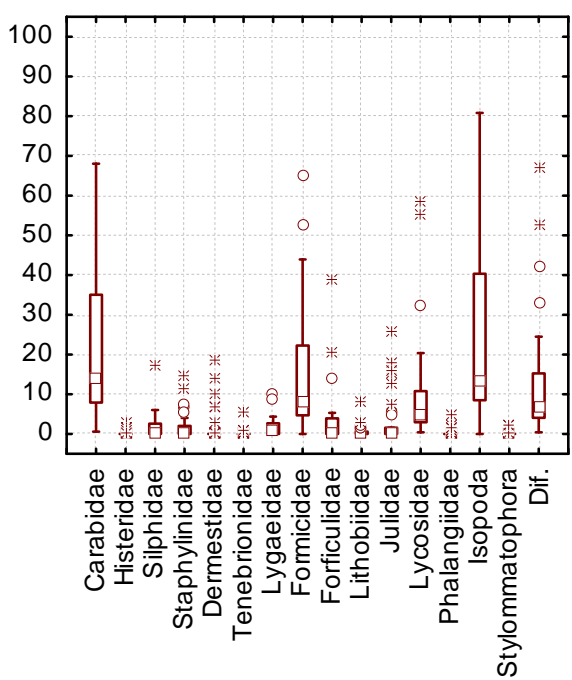

(d)

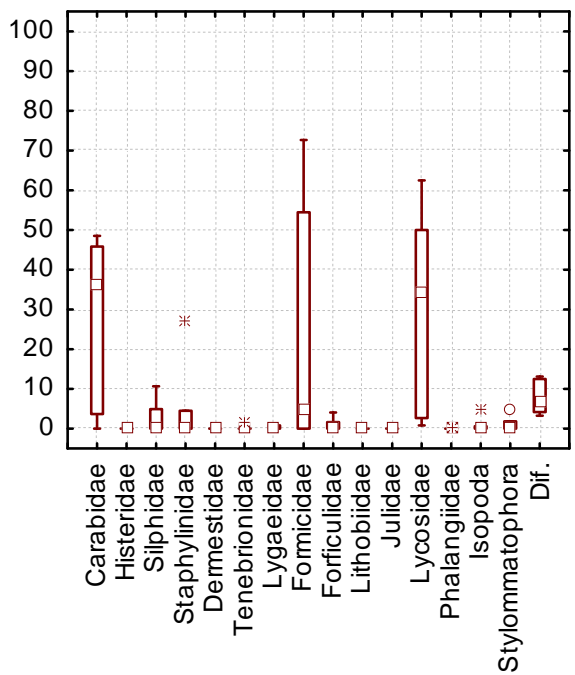

Fig. 4. Taxonomic structure of litter invertebrate communities of shelterbelt and plantation forests in the steppe zone of Ukraine in different moisture conditions: (a) mesoxerophilous, (b) xeromesophilous, (c) mesophilous, (d) hygromesophilous moisture conditions; abscissa - dominant taxonomic groups, ordinate - share of the given taxonomic group in the community by number (\%); Dif. - species of other taxonomic groups 
The basic composition of the litter invertebrate communities of mesoxerophilous moisture conditions (Fig. 4a) is formed by Formicidae (average percentage of dominance in number - 30\%), Julidae (15\%), Silphidae (12\%), Oniscidea (11\%), Lycosidae (10\%), Carabidae (6\%) and Lygaeidae (4\%).

Carabidae (22\%), Formicidae (16\%), Lycosidae (10\%), Julidae (3\%) and Forficulidae (3\%) dominate in the plantations of xeromesophilous moisture conditions (Fig. 4b).

2. Numerical share of size group exceeding $20 \mathrm{~mm}$ body length. The maximum percentage of large forms $(16.5 \%)$ is typical of mesoxerophilous moisture conditions, decreasing significantly to $4.2-9.9 \%$ in the other moisture regimes. In the natural forests of the steppe zone individuals of this size group also do not exceed $10 \%$ in number in most of the surveyed sites. The increase in the proportion of large size groups reflects the total length of the most important trophic chains in an ecosystem, most of which for litter invertebrates of the forests of the temperate zone culminate in zoophages exceeding $20 \mathrm{~mm}$ in body length (in their turn eaten by predatory vertebrates).

The dominance of Carabidae (25\%), Lycosidae (14\%), Lygaeidae (13\%), Formicidae (9\%), Stylommatophora (6\%), Julidae (5\%), Silphidae (5\%), Staphylinidae (4\%) and Oniscidea (3\%) is typical of the communities of mesophilous moisture conditions (Fig. 4c). Lycosidae (32\%), Carabidae (29\%), Formicidae (21\%) and Staphylinidae (5\%) dominate in the shelterbelt and forest plantations of hygromesophilous moisture conditions (Fig. 4d).

The high number of invertebrate families is often combined with the low number of species typical of each given sampling plot representing these families. This pattern is very often observed for Formicidae, Oniscidea (Porcellionidae and Armadillidiidae) and Julidae.

\section{Discussion}

The highest number of individuals, of species and the largest diversity according to the Shannon-Weaver index can be observed in xeromesophilous moisture conditions: here the competition between steppe and forest species that are present simultaneously in the forest ecosystem reaches its maximum intensity. In drier, mesoxerophilous conditions, forest species are minimal in number and generalist and steppe species prevail. The values of the examined characteristics of artificial forest communities correspond to the average level of these characteristics for natural forests of the steppe zone of Ukraine with the single difference that in natural forests the maximum number of specimens, highest number of species and highest readings on diversity indices occur one step higher in the humidity gradient.

In the shelterbelt and forest plantations of the steppe zone, communities of litter invertebrates are formed which are on the whole quite varied and slightly different from those of natural forests. Litter invertebrate communities are more closely linked to the strength and humidity of the litter horizon than to the age of a plantation, its species composition and the degree of anthropogenic pressure on the plantation (Brygadyrenko \& Reshetniak 2014). It is possible to observe a faster adaptation rate of litter invertebrate communities to changing ecological conditions in comparison with the growth rate of the trees in a shelterbelt or plantation forest (the generation duration of invertebrates is measured in months and years while its duration in tree species - in decades and centuries).

Thus, litter moisture is a limiting factor for invertebrate existence in the extreme conditions of forest ecosystems, especially in the south of the steppe zone of Ukraine. The litter invertebrate fauna of the larger plantation forests is much closer in composition to that of communities of natural forests than is the litter fauna of linear shelterbelt plantations. In the southern steppe zone of Ukraine hygromesophilous moisture conditions provide the optimal environment for the litter macroinvertebrate community and it is here that they reach their greatest abundance and species diversity. Ubiquitous and steppe species prevail in extreme 
mesoxerophilous plantations and the proportion of forest species in the community decreases considerably (Korolev \& Brygadyrenko 2014, Svyrydchenko \& Brygadyrenko 2014).

This article is the first attempt to investigate the litter macrofauna of shelterbelt and forest plantations of the steppe zone of Ukraine. This investigation should be of interest for researchers of the process of formation of invertebrate populations in man-made ecosystems. Further studies of formation patterns of the litter invertebrate communities in shelterbelt and forest plantations will allow us to understand the laws of formation and functioning of trophic webs in natural and man-made artificial ecosystems.

\section{References}

Belgard A L. 1971. Steppe Forestry. Lesnaja promyshlennost', Moscow, 336 pp. (in Russian).

Bogaert J, Farina A, Ceulemans R. 2005. Entropy increase of fragmented habitats: A sign of human impact? Ecological Indicators 5, 207-212.

Brygadyrenko V V. 2004. The influence of environmental conditions on the litter animals and phytocoenosis in the forest ecosystems of the Steppe zone of Ukraine. Forestry and Agroforestry 106, 77-83 (in Ukrainian).

Brygadyrenko V V. 2005. Environmental aspects of the interaction of ants (Hymenoptera, Formicidae) with litter invertebrates in steppe forest. Question of Steppe Forestry and Forest Land Reclamation 9, 181-192 (in Ukrainian).

Brygadyrenko V V. 2014. Influence of soil moisture on litter invertebrate community structure of pine forests of the steppe zone of Ukraine. Folia Oecologica 41, 8-16.

Brygadyrenko V V, Reshetniak D Y. 2014. Morphological variability among populations of Harpalus rufipes (Coleoptera, Carabidae): What is more important - the mean values or statistical peculiarities of distribution in the population? Folia Oecologica 41, 109-133.

Faly L I, Brygadyrenko V V. 2014. Patterns in the horizontal structure of litter invertebrate communities in windbreak plantations in the steppe zone of the Ukraine. Journal of Plant Protection Research 54, 414-420.

Hietala-Koivu R, Lankoski J, Tarmi S. 2004. Loss of biodiversity and its social cost in an agricultural landscape. Agriculture, Ecosystems and Environment 103, 75-83.

Irmler U. 2003. The spatial and temporal pattern of carabid beetles on arable fields in northern Germany (SchleswigHolstein) and their value as ecological indicators. Agriculture, Ecosystems and Environment 98, 141-151.

Jabin M, Mohr D, Kappes H, Topp W. 2004. Influence of deadwood on density of soil macro-arthropods in a managed oak-beech forest. Forest Ecology and Management 194, 61-69.

Korolev O V, Brygadyrenko V V. 2014. Influence of individual variation in the trophic spectra of Pterostichus melanarius (Coleoptera, Carabidae) on the adaptation possibilities of its population. Folia Oecologica 41, 34-43.

Major R E, Gowing G, Christie F J, Gray M, Colgan D. 2006. Variation in wolf spider (Araneae: Lycosidae) distribution and abundance in response to the size and shape of woodland fragments. Biological Conservation 132, 98-108.

McNabb D M, Halaj J, Wise D H. 2001. Inferring trophic positions of generalist predators and their linkage to the detrital food web in agroecosystems: A stable isotope analysis. Pedobiologia 45, 289-297.

Moroz K O, Lygun A V, Brygadyrenko V V. 2011. Litter mesofauna seasonal dynamics of anthropogenically transformed ecosystems in Dniprodzerzhinsk city. Visnyk of Dnipropetrovsk University. Biology, ecology, 19, 93-102 (in Ukrainian).

Pielou E C. 1977. Mathematical Ecology. John Wiley \& Sons, New York, 385 pp. 
Roslin T, Koivunen A. 2001. Distribution and abundance of dung beetles in fragmented landscapes. Oecologia 127, 6977.

Shannon C E, Weaver W. 1949. The Mathematical Theory of Communication. University of Illinois Press, Urbana, $125 \mathrm{pp}$.

Svyrydchenko A O, Brygadyrenko V V. 2014. Trophic preferences of Rossiulus kessieri (Diplopoda, Julidae) for the litter of various tree species. Folia Oecologica 41, 202-212.

Thiele H.U. 1977. Carabid beetles in their environments. Springer-Verlag, Berlin, 369 pp.

Didham R.K. 1997. An overview of invertebrate responses to forest fragmentation. In: Watt A.D., Stork N.E., Hunter M.D. (eds.), Forests and Insects. Chapman \& Hall, London, 303-320.

Rainio J, Niemela J. 2003. Ground beetles (Coleoptera: Carabidae) as bioindicators. Biodiversity Conservation 12, 487506.

Wamser S, Dauber J, Birkhofer K, Wolters V. 2011. Delayed colonization of arable fields by spring breeding ground beetles (Coleoptera: Carabidae) in landscapes with a high availability of hibernation sites. Agriculture, Ecosystems and Environment 144, 235-240.

Oxbrough A, French V, Irwin S, Kelly T C, Smiddy P, O'Halloran J. 2012. Can mixed species stands enhance arthropod diversity in plantation forests? Forest Ecology and Management 270, 11-18.

Zeng $\mathrm{H}$, Peltola $\mathrm{H}$, Väisänen $\mathrm{H}$, Kellomäki S. 2009. The effects of fragmentation on the susceptibility of a boreal forest ecosystem to wind damage. Forest Ecology and Management 257, 1165-1173.

Burel F. 1996. Hedgerows and their role in agricultural landscapes. Critical Reviews in Plant Sciences 15, 169-190.

Burel F, Baudry J. 1990. Structural dynamic of a hedgerow network landscape in Brittany, France. Landscape Ecology 4, 197-210.

Cameron R A D, Down K, Pannett D J.1980. Historical and environmental influences on hedgerow snail faunas. Biological Journal of the Linnean Society 13, 75-87.

Dennis P, Fry G L A. 1992. Field margins: can they enhance natural enemy population densities and general arthropod diversity on farmland? Agriculture, Ecosystems and Environment 40, 95-115.

Duelli P, Obrist M K, Schmatz D K.1999. Biodiversity evaluation in agricultural landscapes: above-ground insects. Agriculture, Ecosystems and Environment 74, 33-64.

Hanski I. 1999. Habitat connectivity, habitat continuity, and metapopulations in dynamic landscapes. Oikos 87, 209-219.

Petit S, Burel F. 1998. Effects of landscape dynamics on the metapopulation of a ground beetle (Coleoptera, Carabidae) in a hedgerow network. Agriculture, Ecosystems and Environment 69, 243-252.

de la Peña N M, Butet A, Delettre Y, Morant P, Burel F. 2003. Landscape context and carabid beetles (Coleoptera: Carabidae) communities of hedgerows in western France. Agriculture, Ecosystems and Environment 94, 59-72.

Maudsley M, Seeley B, Lewis O. 2002. Spatial distribution patterns of predatory arthropods within an English hedgerow in early winter in relation to habitat variables. Agriculture, Ecosystems and Environment, 89, 77-89.

Scăunaşu D A, Petrişor A I, Ivanov F M. 2012. Diversity of arthropod communities as an indicator of changes produced by the utilization of silvicultural techniques. Ekoloigia (Slovak Republic), 31, 22-32.

Hendrickx F, Maelfait J P, Van Wingerden W, Schweiger O, Speelmans M, Aviron S, Augenstein I, Billeter R, Bailey D, Bukacek R, Burel F, Diekotter T, Dirksen J, Herzog F, Liira J, Roubalova M, Vandomme V, Bugter R. 2007. How landscape structure, land-use intensity and habitat diversity affect components of total arthropod diversity in agricultural landscapes. Journal of Applied Ecology 44, 340-351. 
Floate K D, Carcamo H, Blackshaw R E, Postman B, Bourassa S. 2007. Response of ground beetle (Coleoptera: Carabidae) field populations to four years of Lepidoptera-specific Bt corn production. Environmental Entomology 36, 1269-1274.

Gaston K J, Blackburn T M. 1996. Range size-body size relationships: evidence of scale dependence. Oikos 75, 479_ 485.

Gerisch M, Schanowski A, Figura W, Gerken B, Dziock F, Henle K. 2006. Carabid beetles (Coleoptera, Carabidae) as indicators of hydrological site conditions in floodplain grasslands. International Review of Hydrobiology 91, 326340. 